\title{
Article \\ Cytotoxic Activity of Piperazin-2-One-Based Structures: Cyclic Imines, Lactams, Aminophosphonates, and Their Derivatives
}

\author{
Jakub Iwanejko ${ }^{1}$, Mahzeiar Samadaei ${ }^{2}{ }^{\oplus}$, Matthias Pinter ${ }^{2}\left(\mathbb{D}\right.$, Daniel Senfter ${ }^{3}$, Sibylle Madlener ${ }^{3}$, \\ Andrzej Kochel ${ }^{4}$, Nataliya Rohr-Udilova ${ }^{2}$ (i) and Elżbieta Wojaczyńska ${ }^{1, *(1)}$ \\ 1 Faculty of Chemistry, Wrocław University of Science and Technology, Wybrzeże Wyspiańskiego 27, \\ 50-370 Wrocław, Poland; jakub.iwanejko@pwr.edu.pl \\ 2 Division of Gastroenterology and Hepatology, Department of Internal Medicine III, \\ Medical University of Vienna, AKH Vienna Währinger Gürtel 18-20, 1090 Vienna, Austria; \\ mahzeiar.samadaei@meduniwien.ac.at (M.S.); matthias.pinter@meduniwien.ac.at (M.P.); \\ nataliya.rohr-udilova@meduniwien.ac.at (N.R.-U.) \\ 3 Department of Pediatrics and Adolescent Medicine, Molecular Neuro-Oncology, \\ Medical University of Vienna, AKH Vienna Währinger Gürtel 18-20, 1090 Vienna, Austria; \\ daniel.senfter@meduniwien.ac.at (D.S.); sibylle.madlener@meduniwien.ac.at (S.M.) \\ 4 Faculty of Chemistry, University of Wrocław, 14 F. Joliot-Curie St., 50-383 Wrocław, Poland; \\ andrzej.kochel@chem.uni.wroc.pl \\ * Correspondence: elzbieta.wojaczynska@pwr.edu.pl; Tel.: +48-713-202-410
}

\section{check for}

updates

Citation: Iwanejko, J.; Samadaei, M.; Pinter, M.; Senfter, D.; Madlener, S.; Kochel, A.; Rohr-Udilova, N.; Wojaczyńska, E. Cytotoxic Activity of Piperazin-2-One-Based Structures: Cyclic Imines, Lactams, Aminophosphonates, and Their Derivatives. Materials 2021, 14, 2138. https://doi.org/10.3390/ma14092138

Academic Editors: Jacek Ścianowski and Marek Krzeminski

Received: 21 March 2021

Accepted: 19 April 2021

Published: 22 April 2021

Publisher's Note: MDPI stays neutral with regard to jurisdictional claims in published maps and institutional affiliations.

Copyright: (C) 2021 by the authors Licensee MDPI, Basel, Switzerland. This article is an open access article distributed under the terms and conditions of the Creative Commons Attribution (CC BY) license (https:// creativecommons.org/licenses/by/ $4.0 /)$.
Abstract: $\mathrm{N}$-Heterocycles are considered as desirable scaffolds for the development of novel lead compounds for anticancer drug research. Among them, phosphorus-containing amino-derivatives play a crucial role. A series of imines and products of their further reactions with $P$-nucleophiles were obtained starting from vicinal bisamines. Reaction of ethylenediamine and $\alpha$-carbonyl esters yielded in novel unexpected products, which structures were confirmed by crystallographic measurements. The cytotoxic activity evaluation was done on a variety of cell lines including HUH7, AKH12, DAOY, UW228-2, D283, D425, and U251. Human umbilical vein endothelial cells (HUVECs) were used as control. Two of the tested compounds, bearing TADDOL-derived, and trifluoromethyl substituents showed a significant effect on cell viability, though comparable to nonmalignant cells.

Keywords: aminophosphonates; cyclic imines; cytotoxic activity; Mannich bases; Pudovik reaction; viability assay

\section{Introduction}

Heterocyclic compounds containing nitrogen atom are known for their wide applications in medicinal chemistry [1]. Among the variety of commercially available drugs containing this structural feature, praziquantel —an anthelmintic agent [2], thiamine-vitamin $\mathrm{B}_{1}$ and vestipitant-antiemetic and anxiolytic drug [3] are worth mentioning. Naturally occurring and synthetical cyclic imines and their derivatives exhibit antiproliferative and antitumor properties (Figure 1). It is known that coordination complexes bearing azaheterocyclic ligands found multiple uses in medical diagnostics, therapy, and are popular contrast agents for magnetic resonance imaging (MRI) [4,5]. Reactions of vicinal diamines with dicarbonyl compounds are an efficient and convenient method for the synthesis of $N$-heterocycles.

In our laboratory, we use chiral bicyclic nitrogen-containing compounds as a platform for the preparation of enantiopure compounds which can find an application for the synthesis of drugs and pharmaceuticals. To this end, we obtained a series of enantiopure $(\mathrm{N}, \mathrm{N}),(\mathrm{N}, \mathrm{P})$, and $(\mathrm{N}, \mathrm{S})$-donating ligands and organocatalysts useful in various enantioselective transformations [6-9], based on the intrinsically chiral skeleton of 2-azanorbornane (2-azabicyclo[2.2.1]heptane) [10]. We established that amino-derivatives 
inhibited a growth of selected lines of cancer cells [11]. During our research on the application of 1,2-diaminocyclohexane in the synthesis of bicyclic systems, we isolated an enantiopure imine 1 (Scheme 1) and used it in the stereoselective Mannich-type reactions with various nucleophiles, including heterocycles (furan, pyrrole, indole) and substituted phenols [12]. We found that Mannich adducts of di-tert-butylphenols to imine $\mathbf{1}$ showed an interesting antiproliferative activity [13]. Recently, a series of chiral phosphorus derivatives (phosphonates, phosphine oxides, phosphonic acids) of the bicyclic imine have been prepared as well $[14,15]$. It can be expected that introduction of this functionality into a nitrogen heterocycle can result in a desired biological activity [16]. Indeed, our research proved that incorporation of phosphorus functionality greatly improves antiproliferative activity of $N$-heterocycles obtained by our group [17]. Cytotoxicity of the products were relatively low to normal cells making them promising compounds for drug development.

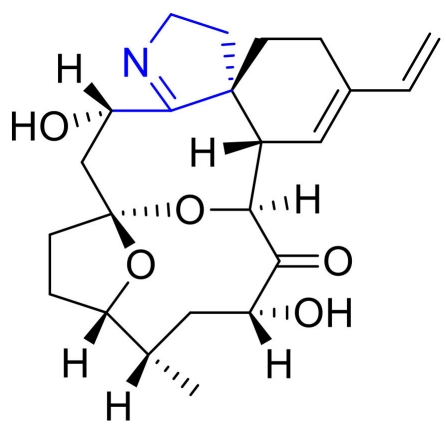<smiles>CCOP(=O)(OCC)C(Nc1nc2cccnc2s1)c1ccccc1F</smiles>

\section{cyclic imines antiproliferative \\ $\alpha$-aminophosphonates antitumor}<smiles>[R]C1N[C@H]2CCCC[C@H]2NC1=O</smiles>

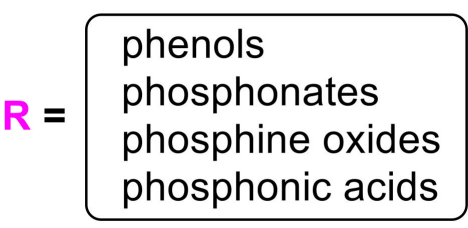

\section{derivatives of bicyclic imine cytotoxic}

Figure 1. $N$-heterocycles of biological importance. Clockwise from top left: portimine A-marine cyclic imine toxin reducing the growth of various cancer cell lines [18]; $\alpha$-aminophosphonate posing antitumor activity [19]; general structure of derivatives of bicyclic imine obtained by our group.<smiles>N[C@@H]1CCCC[C@H]1N</smiles><smiles>[X]C(=O)C(=O)OCC</smiles><smiles>[R17][R]([R20])([R17])C</smiles><smiles>[X]C1=N[C@H]2CCCC[C@H]2NC1=O</smiles>
( 0.5 equiv $)$

Scheme 1. Synthesis of cyclic imines 1-2d.

Numerous heterocyclic compounds exhibit antiproliferative activity. Typically, they are capable of interacting with a variety of biological targets, e.g., by hydrogen bonding. In particular, they are frequently bound in enzyme pockets.

Our compounds share structural features of a heterocycle, namely octahydroquinoxalinone, and aminophosphonate. Similar structural features are present in other anticancer 
compounds. For example, quinoxaline derivatives were studied as anticancer agents and apoptotic inducers against three lines of cancer cells, HCT116, HepG1, and MCF-7. The lead compound was found to cause a noticeable disruption in the cell cycle profile, and induced cell cycle arrest at the G2/M phase boundary [20]. On the other hand, in the investigation on antiproliferative activity of aminophosphonates by Huang et al., the authors concluded that the most promising derivative may induce apoptosis of SK-OV-3 cells through mitochondrion pathways [21].

In our previous studies of antiproliferative activity of phosphonic derivatives of octahydroquinoxalin-2 $(1 \mathrm{H})$-one [17], the analysis of mechanism of their proliferation inhibition of the MV4-11 cells was performed. We found that most active compounds induce cell apoptosis associated with an increased caspase $3 / 7$ activity. However, various derivatives differed by their specific action, decreasing percentage of cells in different cell cycle phases.

In this contribution, we present the results of an extension of our cytotoxic activity study of various chiral $\mathrm{N}$-heterocycles based on vicinal diamines backbone with a focus on imine and aminophosphorus moieties.

\section{Materials and Methods}

Abbreviations: dimethyl sulfoxide (DMSO), glioblastoma (GBM), hepatocellular carcinoma (HCC), human umbilical vein endothelial cells (HUVEC), isopropanol (2-PrOH), lactate dehydrogenase $(\mathrm{LDH})$, medulloblastoma $(\mathrm{MB})$, median toxic dose $\left(\mathrm{TD}_{50}\right)$, room temperature (RT), toluenesulfonyl group (tosyl).

\subsection{Compounds and General Considerations}

The reactants and solvents were received from commercial suppliers and used without additional purification. All melting points are uncorrected and determined by the open capillary method using Apotec ${ }^{\circledR}$ Schmelzpunktbestimmer melting point apparatus (WEPA Apothekenbedarf GmbH \& Co. KG., Hillscheid, Germany). ${ }^{1} \mathrm{H},{ }^{13} \mathrm{C}$ and ${ }^{31} \mathrm{P}$ NMR spectra were collected at $25^{\circ} \mathrm{C}$ using $400 \mathrm{MHz}$ Jeol 400yh (Jeol Ltd., Tokyo, Japan) and $600 \mathrm{MHz}$ Bruker Avance II 600 instruments (Bruker, Billerica, MA, USA). NMR spectra were measured in $\mathrm{CDCl}_{3}$, unless otherwise stated. IR spectra were obtained either as potassium bromide pellets or as liquid films with a Perkin Elmer 2000 FTIR spectrometer (PerkinElmer, Waltham, MA, USA). High-resolution ESI mass spectra were obtained on a Waters LCT Premier XE TOF spectrometer (Waters Corporation, Milford, MA, USA). Optical rotations were determined at $25{ }^{\circ} \mathrm{C}$ with an Optical Activity Ltd. Model AA-5 automatic polarimeter (Optical Activity, Ltd., Ramsey, UK); $[\alpha]^{\mathrm{D}}$ values are expressed in $10^{-1} \mathrm{deg} \mathrm{cm}^{2} \cdot \mathrm{g}^{-1}$. Silica gel 60 was used for both column chromatography and thin-layer chromatography performed with the Merck plates (F254) which were visualized using UV light and iodine vapors.

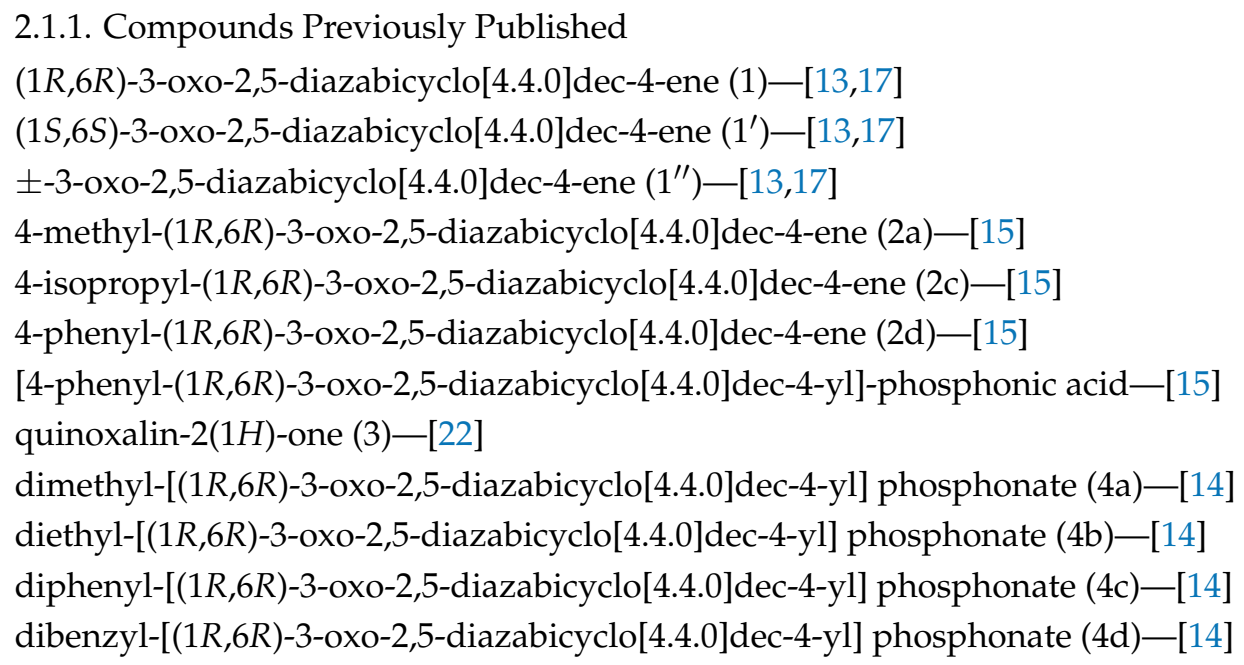


(4-((3aR,8aR)-2,2-dimethyl-6-oxido-4,4,8,8-tetraphenyltetrahydro-[1,3]dioxolo[4,5-e][1,3,2]dioxaphosphepin-6-yl))-(1R,6R)-3-oxo-2,5-diazabicyclo[4.4.0]decan (4e)-[14]

4-(diphenylphosphoryl)-(1R,6R)-3-Oxo-2,5-diazabicyclo[4.4.0]decane (4f)-[14]

[(1R,6R)-3-oxo-2,5-diazabicyclo[4.4.0]dec-4-yl]-phosphonic acid (5a) - [14]

[4-phenyl-(1R,6R)-3-oxo-2,5-diazabicyclo[4.4.0]dec-4-yl]-phosphonic acid (5b)—[15]

3. -hydroxy-3-(trifluoromethyl)piperazin-2-one (6) - [23]

Herein we present the ${ }^{1} \mathrm{H}$ and ${ }^{13} \mathrm{C}$ NMR spectra for the first time (see Supporting Information). 3. -phenyl-5,6-dihydropyrazin-2(1H)-one (7)-[24]

$N, N^{\prime}$-(ethane-1,2-diyl)bis(2-oxo-2-phenylacetamide) (8)-[25]

In this paper we present the ${ }^{1} \mathrm{H}$ and ${ }^{13} \mathrm{C}$ NMR spectra for the first time (see Supporting Information).

\subsubsection{New Compounds}

4-trifluoromethyl-(1R,6R)-3-oxo-2,5-diazabicyclo[4.4.0]dec-4-ene (2b). Typical procedure.

$(1 R, 2 R)$-1,2-diaminocyclohexane ( $2.00 \mathrm{mmol}, 228 \mathrm{mg}, 2.00$ equiv) was dissolved in 2-PrOH (4 mL). Ethyl 3,3,3-trifluoropyruvate ( $1.00 \mathrm{mmol}, 0.133 \mathrm{~mL}, 1.00$ equiv) was introduced to the stirred solution and the mixture was stirred for $24 \mathrm{~h}$ at room temperature $(293 \mathrm{~K})$. The precipitate was filtered off, washed with three portions of 2-PrOH $(3 \times 2 \mathrm{~mL})$ and air-dried overnight.

Colorless solid (0.183 g, 83\%). Mp. $184-185^{\circ} \mathrm{C}$. $[\alpha]_{\mathrm{D}}{ }^{20}-40$ (c 0.90 , acetone). ${ }^{1} \mathrm{H}$ NMR $\left(400 \mathrm{MHz},\left(\mathrm{CD}_{3}\right)_{2} \mathrm{DO}\right): \delta 7.42$ (br. s, $\left.1 \mathrm{H}\right), 3.03(\mathrm{ddd}, J=11.2,9.4,3.7 \mathrm{~Hz}, 1 \mathrm{H}), 2.80-2.86(\mathrm{~m}$, $1 \mathrm{H}), 1.84-1.95(\mathrm{~m}, 2 \mathrm{H}), 1.68-1.74(\mathrm{~m}, 2 \mathrm{H}), 1.18-1.42(\mathrm{~m}, 4 \mathrm{H}) .{ }^{13} \mathrm{C}$ NMR $\left(100 \mathrm{MHz},\left(\mathrm{CD}_{3}\right)_{2} \mathrm{DO}\right)$ : $\delta 164.9,123.4(\mathrm{q}, J=285.6), 82.7(\mathrm{q}, J=28.9), 57.3,53.5,30.0,29.8,24.0,23.6 . \mathrm{IR}(\mathrm{KBr}): 3351$, $3211,3108,2949,2888,2869,1679,1652,1477,1427,1192,1155,1061,1000,806 \mathrm{~cm}^{-1}$. HRMS $(\mathrm{ESI}+, \mathrm{m} / \mathrm{z})$ : calcd. for $\mathrm{C}_{9} \mathrm{H}_{12} \mathrm{~F}_{3} \mathrm{~N}_{2} \mathrm{O}\left([\mathrm{M}+\mathrm{H}]^{+}\right), 221.0902$, found, 221.0910.

3,8-Diphenyl-1,4,7,10-tetraazacyclododeca-3,7-diene-2,9-dione (9); Typical procedure

Ethylenediamine ( $10.0 \mathrm{mmol}, 601 \mathrm{mg}, 0.668 \mathrm{~mL}, 1.00$ equiv) was dissolved in 2-PrOH (20 mL). Ethyl 2-oxo-2-phenylacetate ( $10.0 \mathrm{mmol}, 1.78 \mathrm{~g}, 1.00$ equiv) was then added and the resulting mixture was stirred at $293 \mathrm{~K}$ for $48 \mathrm{~h}$. After removal of solvent in vacuo, the products were isolated by chromatography on silica gel column (eluent: $\mathrm{CH}_{2} \mathrm{Cl}_{2} / \mathrm{MeOH}$ $80: 20 v / v)$.

Colorless solid (0.045 g, 13\%). Mp. 291-293 ${ }^{\circ} \mathrm{C} .{ }^{1} \mathrm{H}$ NMR $\left(600 \mathrm{MHz}, \mathrm{DMSO}-\mathrm{d}_{6}\right): \delta 8.70$ (br. s, 2H), 7.72-7.74 (m, 4H), 7.46-7.52 (m, 6H), 4.08 (br. s, $4 \mathrm{H}), 3.40$ (br. s, 2H), 3.03 (br. s, 2H). ${ }^{13} \mathrm{C}$ NMR (151 MHz, DMSO-d 6 ): $\delta 167.3$ (2C overlapped), 165.9 (2C overlapped), 135.1 (2C overlapped), 131.3 (2C overlapped), 129.0 (4C overlapped), 127.7 (4C overlapped), 55.6 (2C overlapped), 37.2 (2C overlapped). HRMS (ESI+, $m / z)$ : calcd. for $\mathrm{C}_{20} \mathrm{H}_{21} \mathrm{~N}_{4} \mathrm{O}_{2}([\mathrm{M}+$ $\left.\mathrm{H}]^{+}\right), 349.1664$, found, 349.1659 .

Hexahydroimidazo[1' $\left.2^{\prime}: 3,4\right]$ imidazo[1,2-a]pyrazine-5,10(4aH,6H)-dione (10). Typical procedure.

Ethylenediamine $(0.668 \mathrm{~mL}, 10.0 \mathrm{mmol})$ was dissolved in ethanol $(20 \mathrm{~mL})$. To the stirred solution ethyl glyoxalate ( $\sim 50 \%$ in toluene, $2.10 \mathrm{~mL}, 10.0 \mathrm{mmol}, 1.00$ equiv) was introduced, followed by stirring for $48 \mathrm{~h}$ at room temperature $(293 \mathrm{~K})$. Solvents were evaporated under vacuo, and the products were purified on a silica gel column (eluent: $\mathrm{CH}_{2} \mathrm{Cl}_{2} / \mathrm{MeOH}$ 80:20 v/v).

Colorless solid (0.153 g, 78\%). Mp. $185-187^{\circ} \mathrm{C} .{ }^{1} \mathrm{H}$ NMR $\left(500 \mathrm{MHz}, \mathrm{D}_{2} \mathrm{O}\right): \delta 4.68(\mathrm{~d}$, $J=1.5 \mathrm{~Hz}, 1 \mathrm{H}), 4.44(\mathrm{~d}, J=1.0 \mathrm{~Hz}, 1 \mathrm{H}), 3.73-3.81(\mathrm{~m}, 1 \mathrm{H}), 3.24-3.37(\mathrm{~m}, 3 \mathrm{H}), 3.09$ (ddd, $J=12.5,5.5,1.0 \mathrm{~Hz}, 1 \mathrm{H}), 3.01(\mathrm{ddd}, J=12.2,6.0,1.5 \mathrm{~Hz}, 1 \mathrm{H}), 2.87(\mathrm{dq}, J=12.0,5.5 \mathrm{~Hz}, 1 \mathrm{H})$ $2.43(\mathrm{dq}, J=11.5,6.0 \mathrm{~Hz}, 1 \mathrm{H}) .{ }^{13} \mathrm{C}$ NMR $\left(100 \mathrm{MHz}, \mathrm{DMSO}-\mathrm{d}_{6}\right): \delta 169.5,168.5,79.4,75.9$, 55.4, 43.8, 39.9, 37.2. IR (KBr): 3433, 3319, 3224, 2933, 2882, 1690, 1667, 1473, 1328, 1137, $1084,975,806 \mathrm{~cm}^{-1}$. HRMS (ESI+, $\left.m / z\right)$ : Found, 197.1032; calcd. for $\mathrm{C}_{8} \mathrm{H}_{13} \mathrm{~N}_{4} \mathrm{O}_{2}([\mathrm{M}+$ $\left.\mathrm{H}]^{+}\right), 197.1039$. 


\subsection{Single Crystal X-ray Structure Determination of 8,9 and 10}

Crystallographic measurements for 8, 9 and 10 were collected at $100(2) \mathrm{K}$ with Kgeometry diffractometers: Xcalibur Ruby and KM4 Sapphire 2 CCD detector (for 8) equipped with an Oxford Cryosystems cooler, using Mo-K $\alpha$ radiation $(\lambda=0.71073 \AA$, graphite monochromator). CrysAlisPro software was used for data collection, cell refinement, data reduction and analysis [26]. CrysAlisPro was also applied for introduction of analytical absorption correction. SHELXS [27] was used for solving crystal structures, and refinement on $\mathrm{F}^{2}$ by a full-matrix least squares technique was performed with SHELXL2014/16 [28] using anisotropic thermal parameters for all the ordered non- $\mathrm{H}$ atoms. $\mathrm{H}$ atoms were repositioned in their calculated positions in the final refinement cycles, and treated as riding atoms, with $\mathrm{C}-\mathrm{H}=0.95-0.98 \AA$, and with $\mathrm{U}_{\text {iso }}(\mathrm{H})=1.2 \mathrm{U}_{\text {eq }}(\mathrm{C})$ for $\mathrm{CH}, \mathrm{CH}_{2}$. All figures were prepared using DIAMOND program [29].

CCDC (2057703-10, 2057704-9, 2062566-8) contain the supplementary crystallographic data for this paper. These data can be obtained free of charge via www.ccdc. cam.ac.uk/data_request/cif, by e-mailing data_request@ccdc.cam.ac.uk, or by contacting the Cambridge Crystallographic Data Centre, 12 Union Road, Cambridge CB2 1EZ, UK; fax: $+44(0) 1223-336033$.

\subsection{Biological Activity Analysis}

\subsubsection{Cell Lines and Culture Conditions}

The human HCC cell line, HUH7 was purchased from ATCC (LGC standards GmbH, Wesel, Germany). The Austrian human HCC cell line AKH12 has been well characterized [30] and was kindly provided by Prof. Bettina Grasl-Kraupp. HUH7 cells were cultured in DMEM-Dulbecco's Modified Eagle Medium (Thermo Fisher Scientific, Waltham, MA, USA) containing 10\% heat inactivated fetal bovine serum (FBS) (Sigma-Aldrich, St. Louis, MO, USA), $1 \%$ penicillin-streptomycin $(10,000 \mathrm{U} / \mathrm{mL}$ ) (Thermo Fisher Scientific, Waltham, MA, USA), and 1\% Minimum Essential Medium Non-Essential Amino Acids $(100 \times)$ (Thermo Fisher Scientific, Waltham, MA, USA). AKH12 cells were cultured in RPMI-1640 Medium (Sigma-Aldrich, St. Louis, MO, USA) containing 10\% heat inactivated FBS. DAOY and D283Med (short D283) medulloblastoma cells were purchased from ATCC (LGC standards GmbH, Wesel, Germany). D425Med (short D425) and UW228-2 were provided by Thomas Ströbel from the Institute of Neurology Medical University of Vienna. The cells were cultured in Dulbecco's Modified Eagle Medium (Sigma-Aldrich, St. Louis, MO, USA) containing 10\% FBS (Sigma-Aldrich, St. Louis, MO, USA), 2\% L-Glutamine (Sigma-Aldrich, St. Louis, MO, USA), and 0.2\% Normocin (Sigma-Aldrich, St. Louis, MO, USA). U-251 MG (short U251) glioblastoma cell line was purchased from Sigma-Aldrich and cultured in Dulbecco's Modified Eagle Medium (Sigma-Aldrich, St. Louis, MO, USA) containing 10\% FBS (Sigma-Aldrich, St. Louis, MO, USA), 2\% L-Glutamine (Sigma-Aldrich, St. Louis, MO, USA), and 0.2\% Normocin (Sigma-Aldrich, St. Louis, MO, USA). HUVEC cells were provided by Brigitte Winter from the Department of Surgery Medical University of Vienna and were grown in Endothelial Cell Growth Medium-2 BulletKitTM (Lonza, Basel, Switzerland) under standard tissue culture condition. All cells were incubated at $37^{\circ} \mathrm{C}$ in a $5 \% \mathrm{CO}_{2}$ atmosphere.

\subsubsection{Neutral Red Cell Viability Assay (Adherent Cell Lines)}

Neutral red assay was applied for cell viability determination as described previously [31]. $3 \times 10^{4}$ cells were placed in 24-well plates and grown for $24 \mathrm{~h}$ prior to treatment with compounds. After treatment for $24 \mathrm{~h}$, cells were incubated at $37^{\circ} \mathrm{C}$ with neutral red dye at $50 \mu \mathrm{g} / \mathrm{mL}$ concentration in serum free medium for $2 \mathrm{~h}$. Cells were washed twice with PBS and incubated with $1 \% \mathrm{CH}_{3} \mathrm{COOH}$ in $70 \% \mathrm{C}_{2} \mathrm{H}_{5} \mathrm{OH}$. Concentration of the dye was determined photometrically at $562 \mathrm{~nm}$. The percentage of survival was expressed as ratio of survival against cells treated with vehicle (DMSO; indicated as $0 \mu \mathrm{M}$ concentration). $\mathrm{TD}_{50}$ was defined as the concentration of compound required to eliminate half of cells after a specified test duration. 


\subsubsection{CellTiter-Blue Cell Viability-Assay (Suspension Cell Line)}

One day before treatment $2 \times 10^{4} \mathrm{D} 425 \mathrm{Med}$ cells were seeded in 24-well plates and incubated at $37{ }^{\circ} \mathrm{C}$ in a humidified atmosphere containing $5 \% \mathrm{CO}_{2}$. The cells were treated with investigated piperazin-2-one derivatives for $24 \mathrm{~h}$. A cell viability assay was performed using the CellTiter Blue Reagent (Promega, Fitchburg, WI, USA) in agreement with the manufacturer's protocol. As the method for the cell viability was changed for this cell line, we applied the same method for HUVEC cell line for comparison. Three independent experiments were performed. The percentage of survival was expressed as ratio of survival against of DMSO-treated cells (indicated as $0 \mu \mathrm{M}$ concentration).

\subsubsection{Determination of Lactate Dehydrogenase (LDH)}

The release of lactate dehydrogenase into culture media was determined by a cytotoxicity detection kit from Roche Diagnostics according to the manufacturer's instruction. Triton X 100-lysed cells with the maximum LDH activity were considered as a 100\% positive control. DMSO used as the vehicle control.

\section{Results and Discussion}

\subsection{Chemistry}

Chiral, enantiomerically pure imine $(1 R, 6 R)-1$ was prepared from $(1 R, 2 R)-1,2$-diaminocyclohexane (DACH) and ethyl glyoxylate as described previously [13] (Scheme 1). Using appropriate reactants, compound $\mathbf{1}$ was also prepared as $(S, S)$ enantiomer $\left(\mathbf{1}^{\prime}\right)$ as well as a racemate $\left(\mathbf{1}^{\prime \prime}\right)$. A series of enantiopure 4 -substituted derivatives $\mathbf{2 a - 2 d}$ were obtained from $\mathrm{DACH}$ and ethyl esters of ketoacids [15].

Also an achiral quinoxalin-2(1H)-one 3 was prepared from o-phenylenediamine and ethyl glyoxylate (Scheme 2).<smiles>Nc1ccccc1N</smiles><smiles>CCOC(=O)C=O</smiles>

(0.5 equiv)

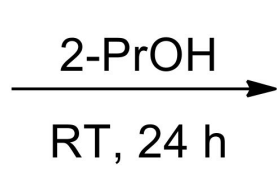

$$
\mathrm{RT}, 24 \mathrm{~h}
$$<smiles></smiles>

(3), $99 \%$

Scheme 2. Synthesis of aromatic cyclic imine 3.

As previously described, cyclic imine 1 reacts with a variety of nucleophiles (Scheme 3). Addition of phosphorus derivatives proceeded with generally high yields, but low diastereoselectivity, yielding aminophophonates $\mathbf{4 a}-\mathbf{4 e}$ and phosphine oxide $\mathbf{4 f}$ as diastereomeric mixtures [14]. Isomers of $4 \mathbf{e}$ were separated using column chromatography, however further studies showed that epimerization of those stereoisomers slowly occurs in solution. For this reason, we used mixtures of epimers in cytotoxicity testing.

In addition, two phosphonic acids $\mathbf{5 a}[14]$ and $\mathbf{5 b}$ [15] were prepared via formation of silyl esters followed by methanolysis (Scheme 4); this time, the reaction yielded mainly one (in case of 5a, dr 70:30) or exclusively one diastereomer (for $\mathbf{5 b}$ ).

We turned our attention towards the synthesis of monocyclic compounds, such as 3-hydroxy-3-(trifluoromethyl)piperazin-2-one 6 , by conducting the reactions of ketoesters with ethylenediamine. The results of these preparations were found dependent on the structure of carbonyl substrate. The presence of highly electrophilic $-\mathrm{CF}_{3}$ moiety led to the formation of hydrate form of imine in a quantitative yield (Scheme 5). 

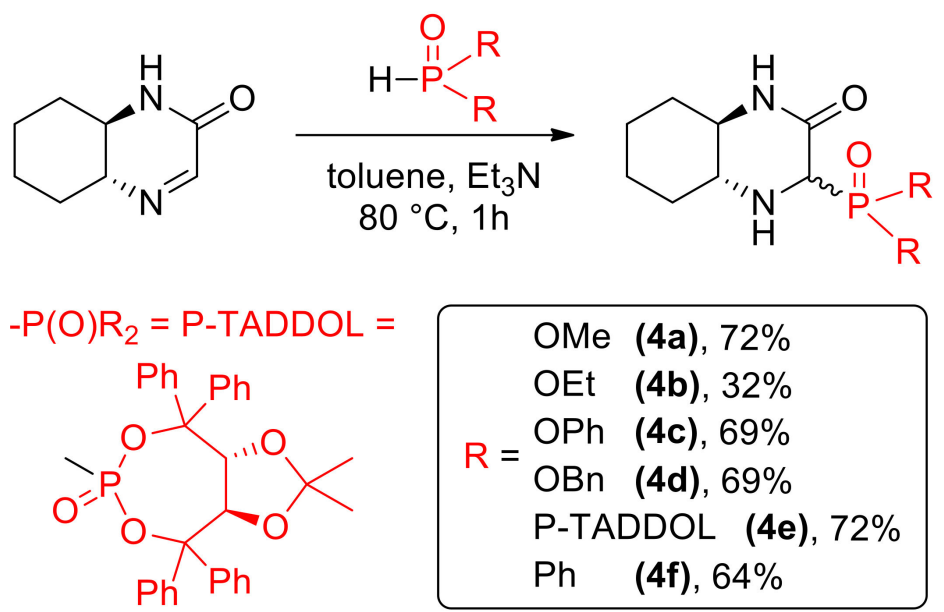

Scheme 3. Nucleophilic $\mathrm{C}=\mathrm{N}$ addition of phosphorus nucleophiles.<smiles>[X]C1=NC2CCCCC2NC1=O</smiles>

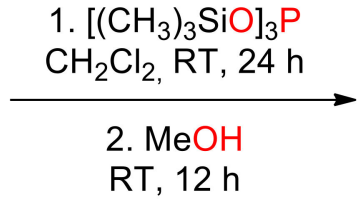<smiles>[X]C1(P)NC2CCCCC2NC1=O</smiles>
$\mathrm{RT}, 12 \mathrm{~h}$

Scheme 4. Synthesis of aminophosphonic acids $\mathbf{5 a}$ and $\mathbf{5 b}$.

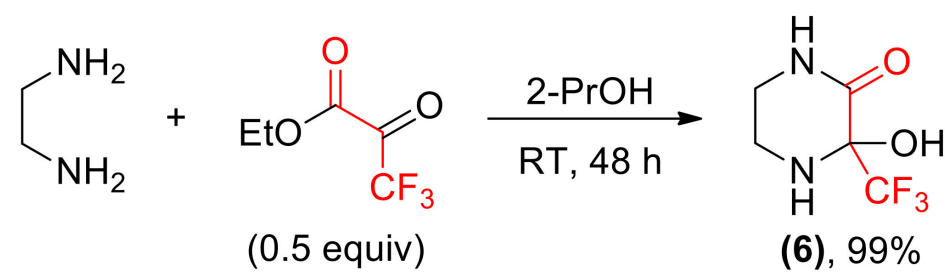

Scheme 5. Synthesis of imine hydrate 6 .

Reaction of ethylenediamine and ethyl benzoylformate yielded a complex mixture from which three main products: a cyclic imine 7 , a $\mathrm{C}_{2}$-symmetrical amide 8 and a macrocyclic compound 9 were isolated (Scheme 6). The structure of two latter products in the solid state was proven by $\mathrm{X}$-ray measurements (Figures 2 and 3).<smiles>O=C(NCCNC(=O)C(=O)c1ccccc1)C(=O)c1ccccc1</smiles><smiles>[R17][R7]([H])([H])C(=O)C(=O)C(=O)OCC</smiles>

(7), $63 \%$

(8), $4 \%$

(0.5 equiv)<smiles>O=C1N=CCN=C(c2ccccc2)C(=O)NCCN=C1c1ccccc1</smiles>

(9), $13 \%$

Scheme 6. Reaction between ethylenediamine and benzoylformate. 


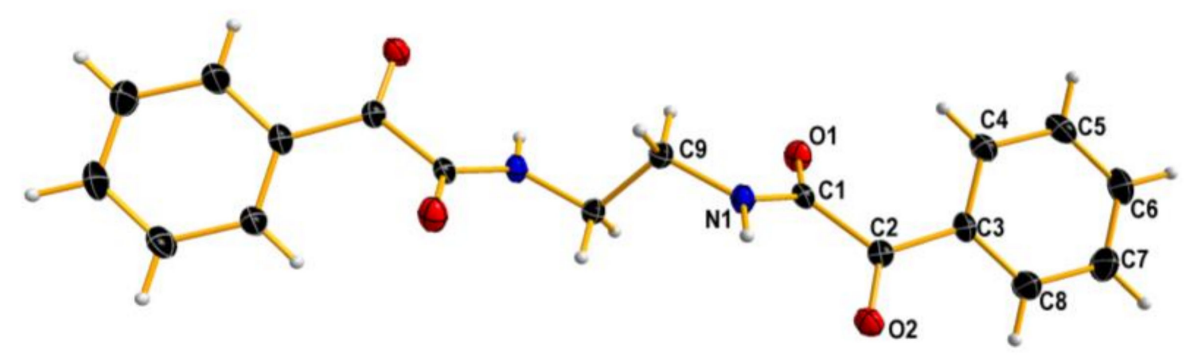

Figure 2. X-ray structure of 8. Displacement ellipsoids are shown at the $50 \%$ probability level. Hydrogen atoms are depicted as small spheres of arbitrary radii.

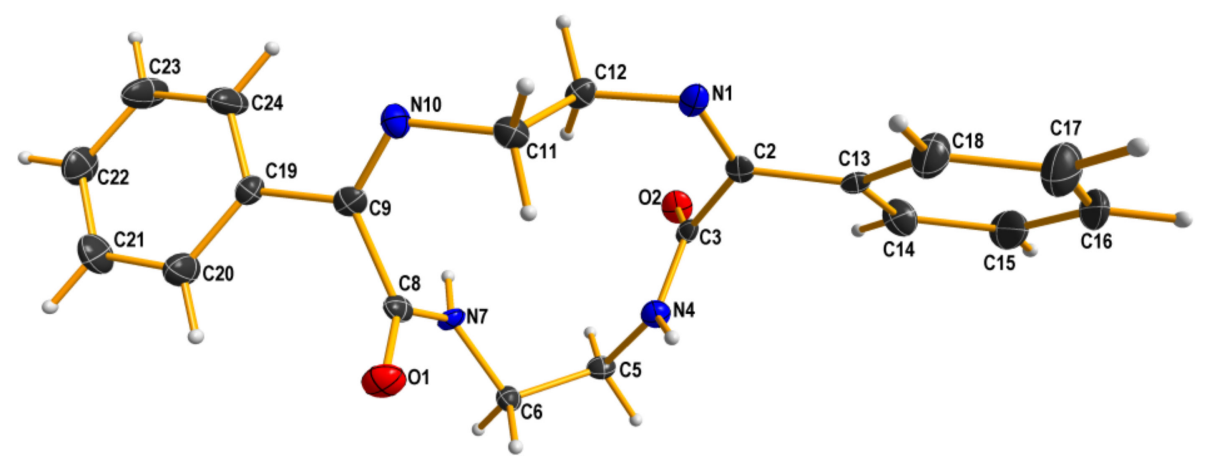

Figure 3. X-ray structure of 9. Displacement ellipsoids are shown at the 50\% probability level. Hydrogen atoms are drawn as small spheres of arbitrary radii.

To our surprise, ethylenediamine reacted with ethyl glyoxylate in a completely different manner: instead of analogs of compounds 6-9, a tricyclic dilactam 10 was formed. This unexpected product can pose as an useful scaffold for organic synthesis. The structure of compound 10 in chloroform solution was established by 2D NMR techniques, and was identical with solid state structure obtained from X-ray measurements (Figure 4). It is also worth noting that the formation of the tricyclic product is diastereoselective-both stereocenters have the same configuration. Certainly, one cannot expect enantioselective formation of a specific stereoisomer, and the compound is racemic.

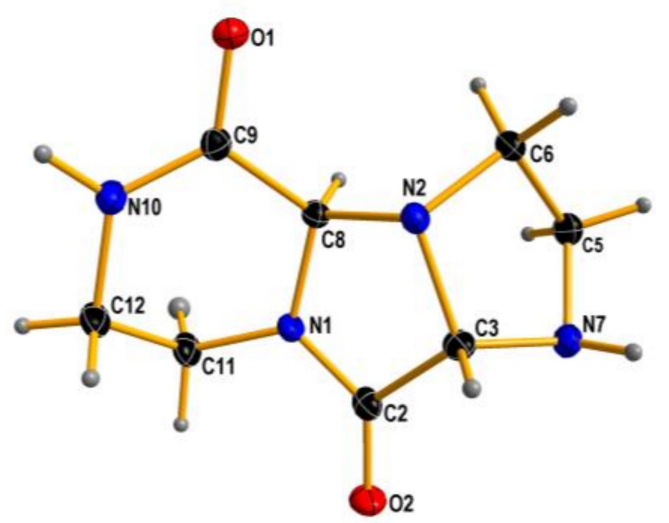

Figure 4. X-ray structure of 10. Displacement ellipsoids are displayed at the $50 \%$ probability level. Hydrogen atoms presented as small spheres of arbitrary radii.

A similar aza-heterocyclic scaffold was obtained by $\mathrm{Li}$ and co-workers via a fivecomponent cyclization of $N$-tosyl-ethylenediamine with glyoxal in methanol [32]. The authors noticed the relationship between the stoichiometry of starting materials and the structure of the obtained $\mathrm{N}$-heterocycle in the presence of transition metal salts as catalysts. 
Various molar ratio directed the reaction towards synthesis of monocyclic imine, tricyclic tetraamine or double bicyclic structure. Our approach is quite simpler, and the use of catalysts was not necessary. We observed a dependence between ethyl glyoxylate form used and the yield of tricyclic product. As seen in Table 1, the lowest yield was obtained using glyoxyate prepared in situ by cleavage of diethyl tartrate with periodic acid in diethyl ether (entry 1) [12]. A slight improvement was observed when this starting material was obtained immediately before the synthesis, isolated and used right after (entry 2). The use of a commercially available polymeric form ( $47 \%$ solution in toluene) led to higher yields (entries 3-5). By elongation of the reaction time, we were able to obtain compound $\mathbf{1 0}$ with a relatively good efficiency.

Table 1. Synthesis of tricyclic dilactam 10.

\begin{tabular}{cccc} 
Sthyl Glyoxylate & Solvent & $\mathrm{T}, \boldsymbol{h}$ & Yield, $\%$ \\
(2.0 equiv) & $\mathrm{Et} 2 \mathrm{O}$ & 48 & 24 \\
$\begin{array}{c}\text { obtained in situ } \\
\text { obtained before synthesis }\end{array}$ & $\mathrm{EtOH}$ & 48 & 34 \\
$\begin{array}{c}\text { polymeric form } \\
\text { polymeric form } \\
\text { polymeric form }\end{array}$ & $\mathrm{EtOH}$ & 48 & 44 \\
$\mathrm{EtOH}$ & $\mathrm{EtOH}$ & 720 & 79 \\
\hline
\end{tabular}

Using a presented set of reactions, we obtained a series of various nitrogen-based heterocycles for cytotoxic activity tests. Structural variations of the compounds was applied to broadly evaluate and discuss the structure-activity relationship. Due to the poor solubility in DMSO, compounds $\mathbf{9}$ and $\mathbf{1 0}$ were excluded from the cellular in vitro assays.

\subsection{Cytotoxic Effect of Tested Compounds}

\subsubsection{Primary Evaluation of the Anti-Cancer Activity of the Compounds}

The general approach to the evaluation of biological activity of investigated compounds followed the one described in our previous study on sulfonamides based on 2azanorbornane skeleton [33]. All compounds were dissolved in dimethyl sulfoxide (DMSO). In our experimental design, all compounds that reduced cells viability by more than $50 \%$ at $50 \mu \mathrm{M}$ concentration after $24 \mathrm{~h}$ were considered as positive hints and were eligible for lactate dehydrogenase (LDH) cytotoxicity assay. To assess the anti-cancer activity of compounds, we have tested hepatocellular carcinoma (HCC), medulloblastoma (MB), and glioblastoma (GBM) cell lines. Further, to compare the effects of selected compounds on non-malignant primary cells, we used human umbilical vein endothelial cells (HUVEC).

\subsubsection{Impact of Compounds on HCC Cell Lines}

HCC accounts for a vast majority of liver cancer and is among the leading causes of cancer-related mortality with the highest incidence in Northern and Western Africa and Eastern and South-Eastern Asia [34]. The introduced $50 \mu \mathrm{M}$ of two compounds, 4e and 6 reduced cell viability below TD 50 in HUH7 and AKH12 cell lines (Figures S7A and S9A). The cytotoxicity of mentioned compounds was measured by the LDH release in a dose-dependent manner (Figures S7B and S9B). The efficacy of tested compounds was compared between HCC cells and HUVEC cells. Our results showed a significant activity of both compounds. However, no reduction as compared to HUVEC cells was observed (Figures S8 and S10 and Table 2). 
Table 2. $\mathrm{TD}_{50}$ values (in $\mu \mathrm{M}$ ) of selected compounds tested in malignant and nonmalignant human cells by neutral red method.

\begin{tabular}{cccccccc}
\hline \multirow{2}{*}{ Compounds } & \multicolumn{2}{c}{$\begin{array}{c}\text { Hepatocellular Carcinoma } \\
\text { Cell Lines }\end{array}$} & \multicolumn{2}{c}{ Medulloblastoma Cell Lines } & \multicolumn{2}{c}{$\begin{array}{c}\text { Glioblastoma } \\
\text { Cell }\end{array}$} & $\begin{array}{c}\text { HUVEC Primary } \\
\text { Cells }\end{array}$ \\
\cline { 2 - 8 } & HUH7 & AKH12 & DAOY & UW228-2 & D283 & U251 & \\
\hline $\mathbf{4 e}$ & $31.4 \pm 1.2$ & $36.6 \pm 1.9$ & $12.6 \pm 1.0$ & $30.7 \pm 2.1$ & $32 \pm 1.1$ & $12.7 \pm 1.6$ & $5.2 \pm 0.9$ \\
$\mathbf{6}$ & $19.4 \pm 5.2$ & $32.0 \pm 1.1$ & $16 \pm 1.0$ & $26.8 \pm 1.4$ & $38.4 \pm 2.0$ & $35.0 \pm 2.7$ & $18.7 \pm 1.5$ \\
\hline
\end{tabular}

\subsubsection{Compounds and MB Cell Lines}

$\mathrm{MB}$ considered being the most common malignant brain tumor, comprises a biologically heterogeneous group of embryonal tumor with an estimated 5000-8000 cases per year worldwide [35]. In current classification $\mathrm{MB}$ divided to four molecular subgroups namely, wingless (WNT), sonic hedgehog (SHH), Group 3, and Group 4 each of which is associated with different genetic alteration, age at onset and prognosis [36]. Among the MB cells that we tested, DAOY and UW228-2 belong to SHH subgroup whereas D425 correspond to Group 3, and D283 exhibits features of both Group 3 and Group 4 [37]. We observed that compounds $4 \mathrm{e}$ and 6 with $50 \mu \mathrm{M}$ concentration reduced cell viability in all 4 cell lines (Figures S11A, $\mathrm{S} 13 \mathrm{~A}, \mathrm{~S} 15 \mathrm{~A}$ and S17A). LDH release indicating the loss of membrane integrity was shown in Figures S11B, S13B, S15B, and S17B. The $\mathrm{TD}_{50}$ values for the investigated compounds in all MB cell lines and HUVEC cells are shown in Tables 2 and 3. No significant effects were observed as compared to HUVEC (Figures S12, S14, S16, and S18).

Table 3. $\mathrm{TD}_{50}$ values (in $\mu \mathrm{M}$ ) of selected compounds tested in malignant and nonmalignant human cells by MTT method.

\begin{tabular}{ccc}
\hline Compounds & Medulloblastoma Cell Line D425 & HUVEC Primary Cells \\
\hline $\mathbf{4} \mathbf{e}$ & $5.9 \pm 0.1$ & $7.2 \pm 1.4$ \\
$\mathbf{6}$ & $28.3 \pm 0.9$ & $24.0 \pm 2.3$ \\
\hline
\end{tabular}

\subsubsection{Compounds and Glioblastoma Cell Line}

Despite aggressive therapy glioblastoma is still associated with a dismal prognosis in almost all adult patients [38]. U251 glioblastoma cell line was subjected to $50 \mu \mathrm{M}$ of studied derivatives. Compounds $\mathbf{4 e}$ and $\mathbf{6}$ decreased cell viability by more than $50 \%$ (Figure S19A). The LDH cytotoxicity assay indicating necrotic cell death was performed in a dose-dependent manner (Figure S19B). However, there was no reduction in U251 cells viability as compared to HUVEC (Figure S20). Table 2 presents the $\mathrm{TD}_{50}$ values of tested compounds on U251 and HUVEC cell lines.

The results of our study show that most of the investigated compounds have a negligible effect on the cell viability of the lines tested. A weak activity can be noticed for compound 1, its enantiomer $\mathbf{1}^{\prime}$, and their equimolar mixture $\mathbf{1}^{\prime \prime}$ Interestingly, for two cancer lines racemate exhibited the highest activity among these samples, although the effect was still unsatisfactory. Significantly better results were obtained for two derivatives: a phosphonate bearing big TADDOL—derived moiety $4 \mathbf{e}$, and a monocyclic diamine with trifluoromethyl substituent 6 . Compound $4 \mathrm{e}$ was previously tested in our previous antiproliferative study using other cancer lines and was found as the only active compound [17]. Moreover, a mixture of epimers which was obtained from the synthesis was even more efficient in comparison with a pure enantiomer. The range of applications of compound is wider: in another study, it appeared useful for the treatment and prevention of herpes by inhibition of replication of HSV 1 virus [39]. Apparently, the TADDOL fragment combined with the rigid bicyclic imine skeleton results in high biological activity of this compound.

A similar activity in the current study was observed for a lactam containing trifluoromethyl group 6 . This piperazine-based compound differs from the rest of the investigated 
compounds that bear a bicyclic skeleton. While $\mathrm{NH}, \mathrm{OH}$ and $\mathrm{C}=\mathrm{O}$ fragments offer numerous possibilities of interactions with biological targets by hydrogen bonds, fluorinated groups, and, in particular, $\mathrm{CF}_{3}$ substituent are well recognized pharmacophores [40-42]. Unfortunately, both derivatives were also relatively toxic for non-malignant cells, though for certain lines the selectivity was better. Since the tested compounds may interact with multiple of biological targets, e.g., hydrogen bonding, it is nearly impossible to formulate a hypotheses about their toxic effects on normal cells. Further studies on that effects should be carried out to provide insight into their mechanism of action.

\section{Conclusions}

Reaction of cyclohexanediamine with ketoesters serves as a useful route to chiral cyclic imines which can be converted to a variety of derivatives, including aminophosphonates. Here, checked also the possible use of other diamines in a similar transformation, and found that in case of ethylenediamine the course of the reaction is strongly dependent on the structure of the second reactant. This led to preparation of interesting amides, including a chiral bicyclic dilactam 10 . Another product bearing $\mathrm{CF}_{3}$ substituent exhibited a significant cytotoxic activity.

We examined the effect of the prepared compounds on a variety of malignant cell lines, including HCC, MB and GBM. HUVEC, a non-malignant primary cells were used as a control. Our results indicate that $50 \mu \mathrm{M}$ concentration of compounds $4 \mathbf{e}$ and $\mathbf{6}$ decrease cell viability by more than $50 \%$ in all cell lines tested. Unfortunately, similar compound toxicity was observed in nonmalignant HUVEC cells. Further efforts to improve compound selectivity towards cancer cells are required.

Supplementary Materials: The following are available online at https:/ /www.mdpi.com/article/ 10.3390/ma14092138/s1, Figure S1: (a) ${ }^{1} \mathrm{H}$ NMR and (b) ${ }^{13} \mathrm{C}$ NMR spectra of 4-trifluoromethyl$(1 R, 6 R)$-3-oxo-2,5-diazabicyclo[4.4.0]dec-4-ene (2b), Figure S2: (a) ${ }^{1} \mathrm{H}$ NMR and (b) ${ }^{13} \mathrm{C}$ NMR spectra of 3-hydroxy-3-(trifluoromethyl)piperazin-2-one (6), Figure S3: (a) ${ }^{1} \mathrm{H}$ NMR and (b) ${ }^{13} \mathrm{C}$ NMR spectra of $N, N^{\prime}$-(ethane-1,2-diyl)bis(2-oxo-2-phenylacetamide) (8), Figure S4: (a) ${ }^{1} \mathrm{H} N M R$, (b) ${ }^{13} \mathrm{C}$ NMR and (c) DEPT-135 spectra of 3,8-diphenyl-1,4,7,10-tetraazacyclododeca-3,7-diene-2,9-dione (9), Figure S5: (a) ${ }^{1} \mathrm{H}$ NMR and (b) ${ }^{13} \mathrm{C}$ NMR spectra of hexahydroimidazo[ $\left[1^{\prime}, 2^{\prime}: 3,4\right]$ imidazo[1,2-a]pyrazine5,10(4aH,6H)-dione (10), Figure S6: X-ray structure of hexahydroimidazo[1' $\left.2^{\prime}: 3,4\right]$ imidazo[1,2a]pyrazine-5,10(4aH,6H)-dione (10), Figure S7: Effect of investigated compounds on HUH7 cell line, Figure S8: Impact of aminophosphonates $4 \mathbf{e}$ and $\mathbf{6}$ on HUH7 in contrast to HUVEC, Figure S9: Viability and cytotoxicity effect of investigated compounds on AKH12 cells, Figure S10: Impact of aminophosphonates 4e and 6 on AKH12 compared to HUVEC, Figure S11: Influence of investigated compounds on DAOY cell viability and cytotoxicity, Figure S12: Sensitivity of DAOY to 4e and 6 in contrast to HUVEC cell lines, Figure S13: Effect of studied compounds on viability of UW228-2 cell line, Figure S14: Impact of compounds $4 \mathbf{e}$ and $\mathbf{6}$ on UW228-2 in contrast to HUVEC, Figure S15: Cytotoxicity of studied compounds on D425 cells, Figure S16: Effect of aminophosphonates $4 \mathbf{e}$ and 6 on viability of D425 in comparison with HUVEC cell lines, Figure S17: Influence of studied compounds treatment on D283 cell viability and cytotoxicity, Figure S18: Efficacy of aminophosphonates on cell viability of D283 compared to HUVEC cell lines, Figure S19: The effect of studied compounds on the viability of U251 cells, Figure S20: Efficacy of aminophosphonates 4 e and $\mathbf{6}$ on cell viability of U251 compared to HUVEC cell lines. Table S1: Crystal data and structure refinement for $N, N^{\prime}$-(ethane-1,2diyl)bis(2-oxo-2-phenylacetamide) (8), Table S2: Atomic coordinates $(\times 104)$ and equivalent isotropic displacement parameters $\left(\AA^{2} \times 10^{3}\right)$ for $N, N^{\prime}$-(ethane-1,2-diyl)bis(2-oxo-2-phenylacetamide) (8), Table S3: Bond lengths $[\AA]$ and angles $\left[{ }^{\circ}\right]$ for $N, N^{\prime}$-(ethane-1,2-diyl)bis(2-oxo-2-phenylacetamide) (8), Table S4: Anisotropic displacement parameters $\left(\AA^{2} \times 10^{3}\right)$ for $N, N^{\prime}$-(ethane-1,2-diyl)bis(2oxo-2-phenylacetamide) (8), Table S5: Hydrogen coordinates $\left(\times 10^{4}\right)$ and isotropic displacement parameters ( $\AA 2 \times 103$ ) for $N, N^{\prime}$-(ethane-1,2-diyl)bis(2-oxo-2-phenylacetamide) (8), Table S6: Torsion angles $\left[{ }^{\circ}\right]$ for $N, N^{\prime}$-(ethane-1,2-diyl)bis(2-oxo-2-phenylacetamide) (8), Table S7: Hydrogen bonds for $N, N^{\prime}$-(ethane-1,2-diyl)bis(2-oxo-2-phenylacetamide) (8) [ $\AA^{\circ}$ and ${ }^{\circ}$ ], Table S8: Crystal data and structure refinement for 3,8-Diphenyl-1,4,7,10-tetraazacyclododeca-3,7-diene-2,9-dione (9), Table S9: Atomic coordinates $\left(\times 10^{4}\right)$ and equivalent isotropic displacement parameters $\left(\AA^{2} \times 10^{3}\right)$ for 3,8-Diphenyl-1,4,7,10-tetraazacyclododeca-3,7-diene-2,9-dione (9), Table S10: Bond lengths [ $\AA$ ] 
and angles $\left[{ }^{\circ}\right.$ ] for 3,8-Diphenyl-1,4,7,10-tetraazacyclododeca-3,7-diene-2,9-dione (9), Table S11: Anisotropic displacement parameters $\left(\AA^{2} \times 10^{3}\right)$ for 3,8-Diphenyl-1,4,7,10-tetraazacyclododeca-3,7diene-2,9-dione (9), Table S12: Hydrogen coordinates $\left(\times 10^{4}\right)$ and isotropic displacement parameters $\left(\AA^{2} \times 10^{3}\right)$ for 3,8-Diphenyl-1,4,7,10-tetraazacyclododeca-3,7-diene-2,9-dione (9), Table S13: Torsion angles $\left[{ }^{\circ}\right]$ for 3,8-Diphenyl-1,4,7,10-tetraazacyclododeca-3,7-diene-2,9-dione (9), Table S14: Hydrogen bonds for 3,8-Diphenyl-1,4,7,10-tetraazacyclododeca-3,7-diene-2,9-dione (9), Figure S6: X-ray structure of hexahydroimidazo[ $\left[1^{\prime}, 2^{\prime}: 3,4\right]$ imidazo[1,2-a]pyrazine-5,10(4aH,6H-dione (10), Table S15: Crystal data and structure refinement for hexahydroimidazo $\left[1^{\prime}, 2^{\prime}: 3,4\right]$ imidazo[1,2-a]pyrazine5,10(4aH,6H-dione (10), Table S16: Atomic coordinates $\left(\times 10^{4}\right)$ and equivalent isotropic displacement parameters $\left(\AA^{2} \times 10^{3}\right)$ for hexahydroimidazo[ $\left[1^{\prime}, 2^{\prime}: 3,4\right]$ imidazo[1,2-a]pyrazine-5,10 $(4 \mathrm{a} H, 6 H)$ dione (10), Table S17: Bond lengths $[\AA]$ and angles $\left[{ }^{\circ}\right]$ for hexahydroimidazo $\left[1^{\prime}, 2^{\prime}: 3,4\right]$ imidazo[1,2a]pyrazine-5,10(4aH,6H)-dione (10), Table S18: Anisotropic displacement parameters $\left(\AA^{2} \times 10^{3}\right)$ for hexahydroimidazo[1' $\left.\mathbf{2}^{\prime}: 3,4\right]$ imidazo[1,2-a]pyrazine-5,10(4aH,6H)-dione (10), Table S19: Hydrogen coordinates $\left(\times 10^{4}\right)$ and isotropic displacement parameters $\left(\AA^{2} \times 10^{3}\right)$ for hexahydroimidazo $\left[1^{\prime}, 2^{\prime}: 3,4\right]$ imidazo[1,2-a]pyrazine-5,10(4aH,6H)-dione (10), Table S20: Torsion angles $\left[{ }^{\circ}\right]$ for hexahydroimidazo $\left[1^{\prime}, 2^{\prime}: 3,4\right]$ imidazo[1,2-a]pyrazine-5,10(4aH,6H)-dione (10), Table S21: Hydrogen bonds for hexahydroimidazo[1' $\left.\mathbf{2}^{\prime}: 3,4\right]$ imidazo[1,2-a]pyrazine-5,10(4aH,6H)-dione (10).

Author Contributions: Conceptualization, N.R.-U. and E.W.; Data curation, M.S., D.S., S.M. and J.I.; investigation, M.S., M.P., D.S., S.M., A.K. and J.I.; supervision, N.R.-U. and E.W.; writing the draft paper, N.R.-U., M.S., J.I. and E.W. All authors have read and agreed to the published version of the manuscript.

Funding: This research received no external funding.

Institutional Review Board Statement: Not applicable.

Informed Consent Statement: Not applicable.

Data Availability Statement: Not applicable.

Conflicts of Interest: The authors declare no conflict of interest.

\section{References}

1. Garcia-Castro, M.; Zimmermann, S.; Sankar, M.G.; Kumar, K. Scaffold diversity synthesis and its application in probe and drug discovery. Angew. Chem. Int. Ed. 2016, 55, 7586-7605. [CrossRef] [PubMed]

2. Roszkowski, P.; Maurin, J.K.; Czarnocki, Z. Enantioselective synthesis of (R)-(-)-praziquantel (PZQ). Tetrahedron Asymetry 2006, 17, 1415-1419. [CrossRef]

3. Ratti, E.; Carpenter, D.J.; Zamuner, S.; Fernandes, S.; Squassante, L.; Danker-Hopfe, H.; Archer, G.; Robertson, J.; Alexander, R.; Trist, D.G.; et al. Efficacy of vestipitant, a neurokinin-1 receptor antagonist, in primary insomnia. Sleep 2013, 36, 1823-1830. [CrossRef] [PubMed]

4. Caravan, P.; Ellison, J.J.; McMurry, T.J.; Luffer, R.B. Gadolinium(III) chelates as mri contrast agents: Structure, dynamics, and applications. Chem. Rev. 1999, 99, 2293-2352. [CrossRef]

5. Zhang, Z.; Nair, S.A.; McMurray, T.J. Gadolinium meets medicinal chemistry: MRI contrast agent development. Curr. Med. Chem. 2005, 12, 751-778. [CrossRef]

6. Wojaczyńska, E.; Skarżewski, J. Chelating 2-azanorbornyl derivatives as effective nitrogen-nitrogen and nitrogen-chalcogen donating ligands in palladium-catalyzed asymmetric allylic alkylation. Tetrahedron Asymmetry 2008, 19, 2252-2257. [CrossRef]

7. Wojaczyńska, E. New 2-azanorbornyl derivatives: Chiral (N,N)-donating ligands for asymmetric catalysis. Tetrahedron Asymmetry 2011, 22, 161-166. [CrossRef]

8. Olszewski, T.K.; Wojaczyńska, E.; Wieczorek, R.; Bąkowicz, J. $\alpha$-Hydroxyphosphonic acid derivatives of 2-azanorbornane: Synthesis, DFT calculations, and crystal structure analysis. Tetrahedron Asymmetry 2015, 26, 601-607. [CrossRef]

9. Wojaczyńska, E.; Kamińska, K.; Wojaczyński, J.; Skarżewski, J. Chiral pyrrolidine thioethers and 2-azanorbornane derivatives bearing additional nitrogen functions. Enantiopure ligands for palladium-catalyzed Tsuji-Trost reaction. Arkivoc 2017, ii, 162-172. [CrossRef]

10. Wojaczyńska, E.; Wojaczyński, J.; Kleniewska, K.; Dorsz, M.; Olszewski, T.K. 2-Azanorbornane-A versatile chiral aza-Diels-Alder cycloadduct: Preparation, applications in stereoselective synthesis and biological activity. Org. Biomol. Chem. 2015, 13, 6116-6148. [CrossRef]

11. Kamińska, K.; Wojaczyńska, E.; Wietrzyk, J.; Turlej, E.; Błażejczyk, A.; Wieczorek, R. Synthesis, structure and antiproliferative activity of chiral polyamines based on a 2-azanorbornane skeleton. Tetrahedron Asymmetry 2016, 27, 753-758. [CrossRef]

12. Iwanejko, J.; Wojaczyńska, E.; Wojaczyński, J.; Bąkowicz, J. Stereoselective preparation of chiral compounds in Mannich-type reactions of a bicyclic imine and phenols or indole. Tetrahedron Lett. 2014, 55, 6619-6622. [CrossRef] 
13. Iwanejko, J.; Wojaczyńska, E.; Trynda, J.; Maciejewska, M.; Wietrzyk, J.; Kochel, A.; Wojaczyński, J. New chiral Mannich adducts of di-tert-butylphenols and a bicyclic imine-Synthesis and antiproliferative activity. Tetrahedron 2017, 73, 2276-2282. [CrossRef]

14. Iwanejko, J.; Brol, A.; Szyja, B.; Daszkiewicz, M.; Wojaczyńska, E.; Olszewski, T.K. Hydrophosphonylation of chiral hexahydroquinoxalin-2(1H)-one derivatives as an effective route to new bicyclic compounds: Aminophosphonates, enamines and imines. Tetrahedron 2019, 75, 1431-1439. [CrossRef]

15. Iwanejko, J.; Brol, A.; Szyja, B.; Daszkiewicz, M.; Wojaczyńska, E.; Olszewski, T.K. Aminophosphonates and aminophosphonic acids with tetrasubstituted stereogenic center: Diastereoselective synthesis from cyclic ketimines. Org. Biomol. Chem. 2019, 17, 7352-7359. [CrossRef]

16. Kafarski, P.; Lejczak, B. Biological activity of aminophosphonic acids. Phosphorus Sulfur Silicon Relat. Elem. 1991, 63, 193-215. [CrossRef]

17. Iwanejko, J.; Wojaczyńska, E.; Turlej, E.; Maciejewska, M.; Wietrzyk, J. Octahydroquinoxalin-2(1H)-one-based aminophosphonic acids and their derivatives-biological activity towards cancer cells. Materials 2020, 13, 2393. [CrossRef]

18. Fribley, A.M.; Xi, Y.; Makris, C.; Alves-de-Souza, C.; York, R.; Tomas, C.; Wright, J.L.C.; Strangman, W.K. Identification of portimine $\mathrm{B}$, a new cell permeable spiroimine that induces apoptosis in oral squamous cell carcinoma. ACS Med. Chem. Lett. 2019, 10, 175-179. [CrossRef]

19. Gu, L.; Jin, C. Synthesis and antitumor activity of $\alpha$-aminophosphonates containing thiazole[5,4-b]pyridine moiety. Org. Biomol. Chem. 2012, 10, 7098-7102. [CrossRef]

20. El Newahie, A.M.S.; Nissan, Y.M.; Ismail, N.S.M.; El Ella, D.A.A.; Khojah, S.M.; Abouzid, K.A.M. Design and synthesis of new quinoxaline derivatives as anticancer agents and apoptotic inducers. Molecules 2019, 24, 1175. [CrossRef]

21. Huang, X.; Wang, M.; You, Q.; Kong, J.; Zhang, H.; Yu, C.; Wang, Y.; Wang, H.; Huang, R. Synthesis, mechanisms of action, and toxicity of novel aminophosphonates derivatives conjugated irinotecan in vitro and in vivo as potent antitumor agents. Eur. J. Med. Chem. 2020, 189, 112067. [CrossRef]

22. Dhameliya, T.M.; Chourasiya, S.S.; Mishra, E.; Jadhavar, P.S.; Bharatam, P.V.; Chakraborti, A.K. Rationalization of benzazole-2carboxylate versus benzazine-3-one/benzazine-2,3-dione selectivity switch during cyclocondensation of 2-aminothiophenols/phenols/ anilines with 1,2-biselectrophiles in aqueous medium. J. Org. Chem. 2017, 82, 10077-10091. [CrossRef]

23. Saloutin, V.I.; Piterskikh, I.A.; Pashkevich, K.I.; Kodess, M.I. Reaction of methyl esters of fluorine-containing $\alpha$-keto acids with amines. Bull. Acad. Sci. USSR Div. Chem. Sci. 1983, 32, 2312-2316. [CrossRef]

24. Gräßle, S.; Vanderheiden, S.; Hodapp, P.; Bulat, B.; Nieger, M.; Jung, N.; Bräse, S. Solid phase synthesis of (benzannelated) six-membered heterocycles via cyclative cleavage of resin-bound pseudo-oxazolones. Org. Lett. 2016, 18, 3598-3601. [CrossRef]

25. Hayoz, P.; Ilg, S. Process for the Production of Strongly Adherent Coatings. U.S. Patent No. 8414982, 4 September 2013.

26. CrysAlis Pro. Available online: https:/ / www.rigaku.com/products/crystallography/crysalis (accessed on 21 March 2021).

27. Sheldrick, G.M. A short history of SHELX. Acta Cryst. 2008, A64, 112-122. [CrossRef]

28. Sheldrick, G.M. Crystal structure refinement with SHELXL. Acta Cryst. 2008, C71, 3-8. [CrossRef]

29. Diamond-Crystal and Molecular Structure Visualization. Available online: http://www.crystalimpact.com/diamond (accessed on 21 March 2021).

30. Sagmeister, S.; Eisenbauer, M.; Pirker, C.; Mohr, T.; Holzmann, K.; Zwickl, H.; Bichler, C.; Kandioler, D.; Wrba, F.; Mikulits, W.; et al. New cellular tools reveal complex epithelial-mesenchymal interactions in hepatocarcinogenesis. Br. J. Cancer. 2008, 99, 151-159. [CrossRef]

31. Rohr-Udilova, N.V.; Stolze, K.; Sagmeister, S.; Nohl, H.; Schulte-Hermann, R.; Grasl-Kraupp, B. Lipid hydroperoxides from processed dietary oils enhance growth of hepatocarcinoma cells. Mol. Nutr. Food Res. 2008, 52, 352-359. [CrossRef]

32. Li, Y.; Miao, J.; Liang, Y.; Chen, Z.; Zhang, Z.; Liang, F. Transition metal acetate promoted syntheses of some new n-heterocycles by multicomponent reactions. J. Heterocycl. Chem. 2017, 54, 531-538. [CrossRef]

33. Samadaei, M.; Pinter, M.; Senfter, D.; Madlener, S.; Rohr-Udilova, N.; Iwan, D.; Kamińska, K.; Wojaczyńska, E.; Wojaczyński, J.; Kochel, A. Synthesis and cytotoxic activity of chiral sulfonamides based on the 2-azanorbornane skeleton. Molecules 2020, 25, 2355. [CrossRef]

34. Bray, F.; Ferlay, J.; Soerjomataram, I.; Siegel, R.L.; Torre, L.A.; Jemal, A. Global cancer statistics 2018: GLOBOCAN estimates of incidence and mortality worldwide for 36 cancers in 185 countries. CA Cancer J. Clin. 2018, 68, 394-424. [CrossRef]

35. Ferlay, J.; Soerjomataram, I.; Dikshit, R.; Eser, S.; Mathers, C.; Rebelo, M.; Parkin, D.M.; Forman, D.; Bray, F. Cancer incidence and mortality worldwide: Sources, methods and major patterns in GLOBOCAN 2012. Int. J. Cancer. 2015, 136, 359-386. [CrossRef] [PubMed]

36. Northcott, P.A.; Robinson, G.W.; Kratz, C.P.; Mabbott, D.J.; Pomeroy, S.L.; Clifford, S.C.; Rutkowski, S.; Ellison, D.W.; Malkin, D.; Taylor, M.D.; et al. Medulloblastoma. Nat. Rev. Dis. Primers 2019, 5, 11-20. [CrossRef] [PubMed]

37. Ivanov, D.P.; Coyle, B.; Walker, D.A.; Grabowska, A.M. In vitro models of medulloblastoma: Choosing the right tool for the job. J. Biotechnol. 2016, 236, 10-25. [CrossRef] [PubMed]

38. Helson, L.; Majeed, M. Pleiotropic chemotherapy to abrogate glioblastoma multiforme migration/invasion. Anticancer Res. 2019, 39, 3423-3427. [CrossRef] [PubMed]

39. Wojaczyńska, E.; Iwanejko, J.; Olszewski, T.K.; Grzywa, R.; Sieńczyk, M.; Pyrć, K.; Pachota, M. Zastosowanie Chiralnej Pochodnej (1R, 2R)-diaminocykloheksanu z Podstawnikiem Taddolowym. Patent No. PL P.429779, 29 September 2019, submitted. 
40. Yale, H.L. The Trifluoromethyl group in medical chemistry. J. Med. Chem. 1958, 1, 121-133. [CrossRef] [PubMed]

41. Purser, S.; Moore, P.R.; Swallow, S.; Gouverneur, V. Fluorine in medicinal chemistry. Chem. Soc. Rev. 2008, 37, 320-330. [CrossRef] [PubMed]

42. Wang, J.; Sanchez-Rosello, M.; Acena, J.L.; del Pozo, C.; Sorochinsky, A.E.; Fustero, S.; Soloshonok, V.A.; Liu, H. Fluorine in pharmaceutical industry: Fluorine-containing drugs introduced to the market in the last decade (2001-2011). Chem. Rev. 2014, 114, 2432-2506. [CrossRef] 